\title{
Depletion of naive CD4 T cells by CXCR4-using HIV-1 variants occurs mainly through increased T-cell death and activation
}

\author{
Mette D. Hazenberga , Sigrid A. Otto ${ }^{a}$, Dörte Hamanna , \\ Marijke Th.L. Roos ${ }^{a}$, Hanneke Schuitemakera , Rob J. de Boer ${ }^{b}$ \\ and Frank Miedema ${ }^{a, c}$
}

\begin{abstract}
Objective: Using SCID-Hu mice models and in vitro culture systems, it has been shown that syncytium inducing/CXCR4 using (X4) HIV-1 variants affect thymic function through infection and killing of CXCR4 thymocytes. The effect of X4-emergence on naive, memory and effector T-cell subset kinetics in vivo is, however, not known.

Design: Prospective cohort study.

Methods: Analysis of changes in naive, memory and effector CD4 and CD8 T-cell numbers and cell division before and after the emergence of X4 variants.

Results: Significantly lower numbers of CD4 T cells in patients with X4 variants $(\mathrm{n}=18)$ compared to patients with non-syncytium inducing/CCR5 using variants $(n=74)$ were due to increased loss of naive and CD27 memory CD4 T cells. In addition, emergence of $\mathrm{X} 4$ variants was associated with a small but significant decline in naive CD8 T-cell numbers and increased proportions of dividing CD4 and CD8 naive, memory and effector $T$ cells.

Conclusion: Loss of naive T cells may suggest thymic dysfunction, however, such an effect would explain only part of the accelerated naive CD4 T-cell decline because of the longevity of naive T cells. Our data suggest that the accelerated naive CD4 T-cell decline induced by X4 variants is caused mainly by increased death and recruitment to the memory compartment of these cells.

(c) 2003 Lippincott Williams \& Wilkins
\end{abstract}

\section{AIDS 2003, 17:1419-1424}

Keywords: T-cell subsets, naive T cells, thymus, CXCR4-using HIV-1 variants, T-cell turnover

\section{Introduction}

Whereas primary HIV-1 infection is established by non-syncytium inducing/CCR5 using (R5) viruses, approximately half of all HIV infected patients experience emergence of syncytium inducing/CXCR 4 using (X4) variants, which is associated with a more rapid decline in CD4 $\mathrm{T}$ cell numbers [1,2]. Recently, our laboratory showed that X4 viruses are able to establish productive infection of peripheral blood naive CD4 T cells $[3,4]$. Whereas R5 viruses were predominantly isolated from patient CD4 memory $\mathrm{T}$ cells, $\mathrm{X} 4$ variants were distributed over naive and memory CD4 $\mathrm{T}$ cells [3]. X4 variants were therefore suggested to exercise their harmful effects through enhanced infection and killing of peripheral blood naive $\mathrm{T}$ cells, thereby also affecting their progeny, the CD4 memory $\mathrm{T}$ cells. In addition, given the tropism of $\mathrm{X} 4$ viruses for thymo-

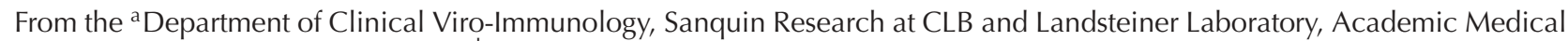
Center, University of Amsterdam, the ${ }^{b}$ Department of Theoretical Biology, Utrecht University, and the ${ }^{\mathrm{c}}$ Department of Human Retrovirology, Academic Medical Center, University of Amsterdam, the Netherlands.

Correspondence to F. Miedema, Department of Clinical Viro-Immunology, Sanquin Research at CLB, Plesmanlaan 125, 1066 CX Amsterdam, the Netherlands.

Received: 30 August 2002; revised: 21 November 2002; accepted: 11 February 2003.

DOI: 10.1097/01.aids.0000072661.21517.f1 
cytes [5-7], the deleterious effect of X4 variants could also be related to impairment of thymic function.

The extent to which $\mathrm{X} 4$ variants affect naive, memory and effector T-cell subset kinetics in vivo is not known. We therefore analysed changes in naive, memory and effector CD4 and CD8 T-cell numbers and division rates longitudinally at timepoints before and after HIV1 seroconversion in patients harboring R 5 variants only, and in patients who experienced conversion to $\mathrm{X} 4$ variants. Our results suggest that the accelerated CD4 T-cell decline associated with the emergence of $\mathrm{X} 4$ variants is related mainly to increased death and activation of naive $\mathrm{T}$ cells rather than to impairment of thymic function.

\section{Materials and methods}

\section{Patients}

We used cryopreserved peripheral blood mononuclear cells (PBMC) from 92 HIV-1 infected participants of the Amsterdam cohort studies on HIV-1 infection and AIDS. Patients were studied before HIV seroconversion and at 1 and 5 years after seroconversion for the effect of emergence of the $\mathrm{X} 4$ phenotype on the loss of naive, memory and effector CD4 and CD8 T cells and on cell division rates. Patient selection was based on the availability of cryopreserved samples at the indicated time points. All patients were initially infected with R5 variants. Emergence of X4 variants occurred in 18 out of these 92 patients during the study period. The mean age of patients who harbored R5 variants and patients who would develop X4 variants was 36 and 35 years, respectively, at the start of the study. None of the patients received highly active antiretroviral therapy at any time. Syncytium inducing X4 variants were detected by co-cultivation of patient PBMC with the MT2 cell line [8]. Cryopreservation was performed using a computerized freezing device that results in optimal quality of viably frozen cells for functional studies [9], and frozen PBMC were stored in liquid nitrogen.

\section{Flow cytometry}

CD4 and CD8 $\mathrm{T}$ cells were subdivided into naive (CD45RO-/CD27+), CD27 memory (CD45RO/ $\mathrm{CD} 27), \mathrm{CD}^{-} 7^{-}$memory (CD45RO/CD27-) and CD27- effector (CD45RO-/CD27-) CD4 and CD8 T-cell subsets as described previously $[10,11]$. Ki67 is a protein that is expressed exclusively by cells that are in cell cycle [12]. For flow cytometric analysis of T-cell subset distribution and cell division, frozen PBMC were thawed and incubated with CD4or CD8- peridinin chlorophyll A protein $\mathrm{mAb}$, CD45RO-phycoerythrin (Becton Dickinson, San Jose, California, USA), biotinylated CD27 mAb (CLB,
Amsterdam, the Netherlands), and, after washing, with streptavidin-allophycocyanin mAb (Becton Dickinson). Lymphocytes were fixed (FACS Lysing Solution, Becton Dickinson), permeabilized (FACS Permeabilization Buffer, Becton Dickinson), and incubated with Ki67fluroesceine isothiocyanate $\mathrm{mAb}$ (Immunotech, Marseille, France). Cells were fixated using Cellfix (Becton Dickinson), and analysed on a FACSCalibur (Becton Dickinson) with Cellquest software.

\section{Statistical analysis}

Differences in viral load, T-cell numbers, and Ki67 expression between patients with R5 variants and patients with X4 variants were compared using nonparametric Mann-Whitney U Test or independent samples $t$ Test, based on the Shapiro-Wilk W test for normality. Dependent samples were analysed using the Wilcoxon Signed Ranks Test, and correlations were estimated by calculating Spearman's correlation coefficients. $P$ values $<0.05$ were considered statistically significant.

\section{Results}

\section{Effect of X4 variants on peripheral blood T-cell numbers}

Ninety-two participants of the Amsterdam Cohort Studies on HIV-1 infection and AIDS were analysed for the effect of X4 variants on peripheral blood T-cell numbers and T-cell division. During the period under study (up to 5 years after HIV-1 seroconversion), 18 of these individuals experienced emergence of $\mathrm{X} 4$ variants and 74 did not. Before HIV-1 seroconversion, CD4 and CD8 T-cell numbers were comparable between the two groups (Table 1). One year after seroconversion, five patients had already experienced emergence of the X4 phenotype. At this timepoint, CD4 and CD8 T-cell numbers in these patients were lower than in patients with $\mathrm{R} 5$ variants and in patients who would experience emergence of the $\mathrm{X} 4$ phenotype during the period under study, but differences were not significant (Table 1). Within 5 years of seroconversion, X4 viruses had developed in 18 patients, 14 of whom were still alive. The median time between the first detection of $\mathrm{X} 4$ variants and evaluation of $\mathrm{T}$-cell kinetics in these patients was 16 months (range, 6-54 months). Patients with $\mathrm{X} 4$ variants at this time point had significantly lower numbers of CD4 $\mathrm{T}$ cells compared with patients who harboured R5 variants (Table 1), confirming previous reports [1,2]. Increased CD4 T-cell loss in these patients was associated with a significant reduction of naive and CD27 memory CD4 T-cell numbers (mean values $166 \pm 126$ and $39 \pm 49 \times 10^{6}$ cells $/ 1$, $P<0.001$, for naive CD4 $\mathrm{T}$ cells; $188 \pm 71$ and $67 \pm 51 \times 10^{6}$ cells $/ 1, P<0.001$, for CD27 memory CD4 T cells; Fig. 1, left panel). No significant differ- 
Table 1. Accelerated CD4 T-cell decline following X4 emergence. Shown are mean \pm SD CD4 and CD8 T-cell numbers $\left(\times 10^{6} / /\right.$ blood) before (pre) and at 1 and 5 years after (post) HIV-1 seroconversion (SC) for patients with R5 variants only and for patients in whom X4 variants emerged during the study period (converters). For converters T-cell numbers before (R5) and after (X4) X4 emergence are shown.

\begin{tabular}{|c|c|c|c|c|c|c|}
\hline & \multicolumn{3}{|c|}{ CD4 } & \multicolumn{3}{|c|}{ CD8 } \\
\hline & Pre SC & 1 year post SC & 5 years post $\mathrm{SC}$ & Pre SC & 1 year post SC & 5 years post $\mathrm{SC}$ \\
\hline R5 only & $\begin{array}{c}880 \pm 356 \\
(\mathrm{n}=44)\end{array}$ & $\begin{array}{c}458 \pm 194 \\
(\mathrm{n}=40)\end{array}$ & $\begin{array}{c}658 \pm 321 \\
(\mathrm{n}=44)\end{array}$ & $\begin{array}{c}644 \pm 279 \\
(\mathrm{n}=62)\end{array}$ & $\begin{array}{c}840 \pm 484 \\
(\mathrm{n}=62)\end{array}$ & $\begin{array}{c}980 \pm 490 \\
(\mathrm{n}=40)\end{array}$ \\
\hline \multicolumn{7}{|c|}{ Converters } \\
\hline R5 & $\begin{array}{c}792 \pm 418 \\
(\mathrm{n}=12)\end{array}$ & na & $\begin{array}{r}533 \pm 222 \\
(\mathrm{n}=12)\end{array}$ & $\begin{array}{r}589 \pm 266 \\
(\mathrm{n}=13)\end{array}$ & $\begin{array}{r}658 \pm 171 \\
(\mathrm{n}=13)\end{array}$ & na \\
\hline X4 & na & $\begin{array}{c}199 \pm 146^{*} \\
(\mathrm{n}=14)\end{array}$ & na & $\begin{array}{c}390 \pm 239 \\
(n=5)\end{array}$ & $\begin{array}{c}726 \pm 567 \\
(\mathrm{n}=5)\end{array}$ & $\begin{array}{c}802 \pm 266 \\
(\mathrm{n}=14)\end{array}$ \\
\hline
\end{tabular}

${ }^{*}$ Significantly lower than in R5 only patients at the same time point. na, Not applicable.
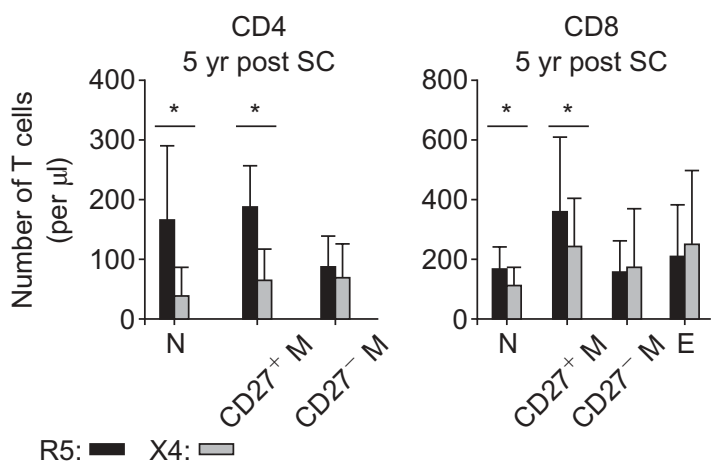

Fig. 1. Emergence of $\mathrm{X} 4$ variants was associated with an accelerated decline in naive and CD27 memory CD4 and CD8 T-cell numbers. Depicted are the number of naive, CD27 memory, CD27 - memory and effector CD4 and CD8 $T$ cells as measured 5 years after seroconversion. $\mathrm{N}$, Naive; CD27+M, CD27 memory; CD27-M, CD27- memory; E, CD27- effector; *, significant difference between R5 $(\mathrm{n}=40)$ and $X 4(\mathrm{n}=14)$ patient groups.

ences in total CD8 T-cell numbers were observed at this time point (Table 1); however, patients with $\mathrm{X} 4$ variants had significantly lower numbers of naive and CD27 memory CD8 T cells compared with patients harbouring R5 variants (mean values $165 \pm 83$ and $112 \pm 63 \times 10^{6}$ cells $/ 1, P<0.05$, for naive CD8 T cells; $364 \pm 250$ and $244 \pm 166 \times 10^{6}$ cells $/ 1, \quad P<$ 0.05, for CD27 memory CD8 T cells; Fig. 1, right panel). Thus, patients with $\mathrm{X} 4$ variants showed an accelerated decline in naive $\mathrm{T}$-cell numbers, that was most pronounced for the naive CD4 $\mathrm{T}$ cells. Whereas patients with $\mathrm{R} 5$ variants had equal numbers of naive CD4 $\mathrm{T}$ cells and of naive CD8 $\mathrm{T}$ cells 5 years after seroconversion, individuals in whom X4 variants developed had significantly lower numbers of naive CD4 $\mathrm{T}$ cells than of naive CD8 $\mathrm{T}$ cells at this time point $(P<0.005$; Fig. 2a).
A
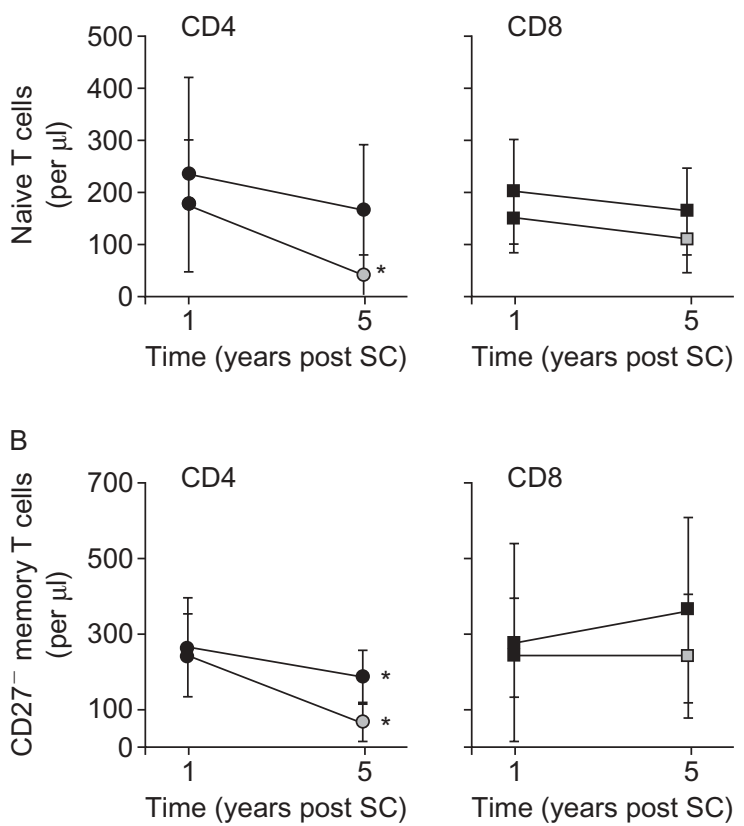

R5:

$-\quad \times 4:-0-\square$

Fig. 2. (a) X4 related accelerated naive T-cell decline was more rapid in the CD4 T-cell pool compared with the CD8 T-cell pool. (b) Individuals experiencing emergence of $X 4$ variants had a more pronounced decline in number of CD4CD27 memory T cells compared with patients with R5 variants only. The latter group showed an expansion of the CD8CD27 memory T-cell pool that was absent in patients harbouring the $X 4$ phenotype. Depicted are mean $( \pm S D)$ naive (a) and CD27 memory (b) CD4 (circles) and CD8 (squares) T-cell numbers of patients with R5 variants (black symbols) and patients with $\mathrm{X} 4$ variants (grey symbols). See tables for patient numbers in each group. ${ }^{*}$, Number of $T$ cells that is significantly lower in X4 patients compared with R5 patients; **, Number of CD4 T cells that is significantly lower than the number of CD8 T cells in the same patient group at that time point $(P<0.05)$. 
Emergence of $\mathrm{X} 4$ virus was also associated with significantly lower numbers of CD27 memory CD4 and CD8 $\mathrm{T}$ cells (Fig. 1). Whereas the difference in number of CD4CD27 memory T cells was caused by a more rapid decline of these cells in patients with $\mathrm{X} 4$ variants, the difference in CD8CD27 memory T-cell numbers was related mainly to an expansion of this subset in patients with $\mathrm{R} 5$ variants that was absent in patients harbouring $\mathrm{X} 4$ virus (Fig. $2 \mathrm{~b}$ ).

\section{Effect of $X 4$ virus on cell division and plasma HIV-1 RNA}

HIV-1 infection is associated with a several fold increase in CD4 and CD8 T-cell division rates [13-16]. In the first year after seroconversion Ki67 expression increased to the same extent both in patients with R5 variants and in those who at this time point harboured R5 variants only but in whom X4 viruses would develop later (Table 2). The five individuals in whom $\mathrm{X} 4$ viruses had developed already at this time point had significantly increased proportions of Ki67CD4 T cells compared with patients with R5 variants and patients who would later convert to the $\mathrm{X} 4$ virus phenotype, but not of Ki67CD8 T cells (Table 2). Five years after seroconversion, the proportion of dividing CD4 and CD8 $\mathrm{T}$ cells was significantly higher in patients with $\mathrm{X} 4$ variants (Table 2). At all time points, increased cell division was observed in naive, CD27 memory, CD27memory and effector CD 4 and CD8 T cells $(P<0.05$; data not shown), and the proportion of Ki67CD4 $\mathrm{T}$ cells correlated significantly with the proportion of Ki67CD8 T cells $(P<0.001$; data not shown). Five years after seroconversion, the number of naive CD4 and CD8 $\mathrm{T}$ cells correlated significantly with the proportion of Ki67 naive CD4 and naive CD8 T cells $(r, \quad-0.678, \quad P<0.001$ and $r=-0.416, \quad P=0.001$, respectively; data not shown).

Plasma HIV-1 RNA was higher in patients who had experienced X4 emergence, but the difference with patients who harboured R5 variants only was not significant $(P>0.05$; Table 3$)$. Neither group showed
Table 3. HIV-1 plasma RNA was not significantly higher in X4 patients. Shown are mean \pm SD HIV- 1 plasma RNA (log copies $/ \mathrm{ml}$ ) at 1 and 5 years post HIV- 1 seroconversion (SC) for patients with R5 variants only and for patients in whom X4 variants emerged during the study period (converters). For converters, HIV-1 plasma RNA before (R5) and after (X4) X4 emergence is shown.

\begin{tabular}{lcc}
\hline & 1 year post SC & 5 years post SC \\
\hline R5 only & $\begin{array}{c}4.69 \pm 4.83 \\
(\mathrm{n}=62)\end{array}$ & $\begin{array}{c}4.64 \pm 4.69 \\
(\mathrm{n}=40)\end{array}$ \\
$\begin{array}{c}\text { Converters } \\
\text { R5 }\end{array}$ & $\mathrm{na}$ \\
X4 & $\begin{array}{c}4.74 \pm 4.81 \\
(\mathrm{n}=13)\end{array}$ & \\
& $\begin{array}{c}5.58 \pm 5.87 \\
(\mathrm{n}=5)\end{array}$ & $\begin{array}{c}5.12 \pm 5.41 \\
(\mathrm{n}=14)\end{array}$ \\
\hline
\end{tabular}

na, Not applicable.

a significant increase in plasma HIV-1 RNA with time (Table 3). Five years after seroconversion, the proportion of Ki67 expressing CD4 and CD8 T cells correlated significantly with plasma HIV-1 RNA $(r=$ 0.484 and $r=0.468, P<0.002$, respectively; data not shown).

\section{Discussion}

In HIV-1 infection, the emergence of X4 HIV-1 variants is associated with a more rapid decline in CD4 $\mathrm{T}$-cell numbers $[1,2]$. Because immature progenitor $\mathrm{T}$ cells in the thymus and mature naive $\mathrm{T}$ cells in the blood express the CXCR 4 co-receptor $[5,6,17,18]$, the deleterious effect of $\mathrm{X} 4$ variants may be related to cytopathic effects directed at mature naive CD4 T cells in the periphery, or at CD4 and CD8 T-cell precursors in the thymus, or both. It has been shown in vitro and in the SCID-hu Thy/Liv mouse model that X4 and R5 variants affect different thymocyte subsets, related to distinct co-receptor expression by maturing thymocytes $[6,7,18,19]$. Similarly, in vitro infection of mature peripheral blood $\mathrm{T}$ cells with $\mathrm{R} 5$ and $\mathrm{X} 4$ variants

Table 2. Increased Ki67 expression in patients with X4 variants. Shown are mean \pm SD proportions of Ki67CD4 and CD8 T cells before (pre) and at 1 and 5 years after (post) HIV-1 seroconversion (SC) for patients with R5 variants only and for patients in whom X4 variants emerged during the study period (converters). For converters, Ki67 expression before (R5) and after (X4) X4 emergence is shown.

\begin{tabular}{|c|c|c|c|c|c|c|}
\hline & \multicolumn{3}{|c|}{ CD4 } & \multicolumn{3}{|c|}{ CD8 } \\
\hline & Pre SC & 1 year post SC & 5 years post SC & Pre SC & 1 year post SC & 5 years post $\mathrm{SC}$ \\
\hline R5 only & $\begin{array}{r}2.7 \pm 1.8 \\
(n=44)\end{array}$ & $\begin{array}{r}8.4 \pm 5.0 \\
(\mathrm{n}=40)\end{array}$ & $\begin{array}{r}2.1 \pm 1.8 \\
(\mathrm{n}=44)\end{array}$ & $\begin{array}{r}6.0 \pm 3.0 \\
(\mathrm{n}=62)\end{array}$ & $\begin{array}{r}6.4 \pm 3.7 \\
(\mathrm{n}=62)\end{array}$ & $\begin{array}{r}6.3 \pm 3.3 \\
(\mathrm{n}=40)\end{array}$ \\
\hline \multicolumn{7}{|c|}{ Converters } \\
\hline R5 & $\begin{array}{r}2.5 \pm 0.8 \\
(\mathrm{n}=12)\end{array}$ & na & $\begin{array}{r}1.9 \pm 0.9 \\
(\mathrm{n}=12)\end{array}$ & $\begin{array}{r}5.5 \pm 2.2 \\
(\mathrm{n}=13)\end{array}$ & $\begin{array}{r}6.1 \pm 1.7 \\
(\mathrm{n}=13)\end{array}$ & na \\
\hline $\mathrm{X} 4$ & na & $\begin{array}{c}13.1 \pm 7.2^{*} \\
(\mathrm{n}=14)\end{array}$ & na & $\begin{array}{c}8.9 \pm 2.6^{*} \\
(\mathrm{n}=5)\end{array}$ & $\begin{array}{c}5.6 \pm 1.2 \\
(\mathrm{n}=5)\end{array}$ & $\begin{array}{c}9.2 \pm 4.4^{*} \\
(\mathrm{n}=14)\end{array}$ \\
\hline
\end{tabular}

*Significantly higher than in R5 only patients at the same time point. na, Not applicable. 
resulted in depletion of naive and memory CD4 T-cell subsets that corresponded with CXCR 4 and CCR 5 co-receptor expression $[4,20]$. In vivo, naive CD4 T cells were found to be exclusively infected by $\mathrm{X} 4$ variants whereas both $\mathrm{R} 5$ and $\mathrm{X} 4$ variants could be isolated from memory CD4 $\mathrm{T}$ cells in agreement with co-receptor expression by these subsets [3]. These and other studies suggest distinct effects of R5 and X4 variants on the composition of the T-cell pool, but no data on the in vivo effect of the emergence of $\mathrm{X} 4$ variants on naive and memory CD4 and CD8 T-cell numbers are available to date.

Here, we show in a cohort study that the more rapid CD4 T-cell decline in patients harbouring X4 variants was associated with a significant loss of naive and CD27 memory CD4 $\mathrm{T}$ cells. In addition, X4 emergence was associated with significantly lower numbers of naive and CD27 memory CD8 T cells. Whereas CD45RA can be re-upregulated on resting, antigenexperienced memory $\mathrm{T}$ cells, CD27 down-regulation upon stimulation is irreversible [21]. Therefore, we consider CD4 and CD8 $\mathrm{T}$ cells that are CD27+ and $\mathrm{CD} 45 \mathrm{RA}+/ \mathrm{CD} 45 \mathrm{RO}-$ as non-reversed truly naive $\mathrm{T}$ cells that have been newly generated. Accelerated loss of $\mathrm{T}$ cells following $\mathrm{X} 4$ emergence involved naive CD8 $\mathrm{T}$ cells and naive CD4 $\mathrm{T}$ cells. This suggests that depletion of both subsets could at least be partly driven by a common factor, such as X4 virus-related reduced naive $\mathrm{T}$-cell production by the thymus. Although direct quantitative measurements of naive $\mathrm{T}$-cell production and death rates are lacking thus far, these numbers can be estimated based on in vivo observations in healthy and T-cell depleted individuals [22]. With an estimated output of $10^{7}-10^{8}$ naive $\mathrm{T}$ cells per day [22], thymic function is relatively low in healthy adults. Estimating a total body count of $10^{11}$ naive CD4 T cells [22], a daily production of $10^{7}-10^{8}$ cells, and assuming that naive $\mathrm{T}$-cell numbers are in steady state, the corresponding naive T-cell death rates are 0.00010.001 per day. After complete abrogation of thymic function, naive T-cell decline can be described as $N_{\mathrm{t}}=N_{0} \mathrm{e}^{-\mathrm{dt}}$, where $N$ is the total body number of naive $\mathrm{T}$ cells and $d$ is the death rate. Patients with $\mathrm{X} 4$ viruses showed a decline in peripheral blood naive $\mathrm{T}$ cell numbers from 150 to $50 \times 10^{6}$ cells $/ 1$ in the present study. For naive T-cell death rates of $d=$ 0.0001 to $d=0.001$ per day, this decline would take 3-30 years. Because the median time from X4 emergence to the moment of analysis, 5 years after seroconversion, in this study was only 16 months, impairment of thymic output cannot explain X4-related accelerated decline of naive $\mathrm{T}$ cells. Although the notion that X4induced impairment of thymic function would affect peripheral blood naive $\mathrm{T}$ cell numbers only slowly is based merely on the above mentioned estimations for $\mathrm{T}$-cell production and death rates, it is compatible with the observation that adult thymectomy does not lead to a significant decline in CD4 T-cell numbers when measured 5 years later $[23,24]$. In addition, naive CD4 $\mathrm{T}$-cell decline in patients with $\mathrm{X} 4$ viruses was much more pronounced than naive CD8 T-cell decline. As CXCR 4 is expressed by triple-negative, immature single-positive and triple-positive thymocytes [25], it seems likely that $\mathrm{X} 4$ variants would affect maturing intrathymic CXCR 4 progenitors of CD4 and CD8 T cells equally. The more rapid decline of naive CD4 Tcell numbers therefore demonstrated that additional factors play a role, such as direct infection and killing of CXCR4-positive naive CD4 T cells [3,4]. Indeed, emergence of $\mathrm{X} 4$ variants has been associated with a 10 - to 100 -fold increase in the number of productively infected naive CD4 T cells [3], which may explain the observed accelerated decline in naive $\mathrm{CD} 4 \mathrm{~T}$ cell numbers in vivo (Fig. 2).

It has been argued that persistently increased immune activation may lead to depletion of naive CD4 and CD8 T cells $[26,27]$. Patients with X4 HIV-1 variants had indeed higher proportions of dividing naive, memory and effector CD4 and CD8 $\mathrm{T}$ cells that correlated with lower T-cell numbers. Previously, we have shown that increased cell division in HIV-1 infected individuals with low T-cell numbers is not a homeostatic response to T-cell depletion, but is mainly driven by continuous virus replication and high proinflammatory cytokine levels [14]. Thus, on a daily basis in patients with X4 variants increased numbers of naive $\mathrm{T}$ cells become activated and migrate to the memory/effector compartment. With time this will lead to a decline in naive $T$-cell numbers, because naive T-cell replacement in adults is very slow and may even be completely abrogated in patients with $\mathrm{X} 4$ variants. In addition, higher proportions of dividing $\mathrm{T}$ cells may facilitate HIV-1 infection, increasing the proportion of productively infected naive and memory $\mathrm{T}$ cells, and elevated levels of immune activation associated with the emergence of X4 variants may lead to increased tissue sequestration of lymphocytes.

Finally, the number of CD27 memory CD4 and CD8 $\mathrm{T}$ cells was also significantly lower in patients with $\mathrm{X} 4$ variants. The decline in CD4CD27 memory $\mathrm{T}$ cells may be related to the increased number of memory CD4 $\mathrm{T}$ cells that can become infected with the enlargement of the target cell population after X4 emergence [3,4]. In addition, depletion of naive CD4 and naive CD8 T cells may also be of relevance here, as these cells now are unable to generate their progeny, CD27 memory T cells [3].

In conclusion, emergence of $\mathrm{X} 4$ variants affected predominantly naive and CD27 memory CD4 T-cell subsets. Because X4-virus induced abrogation of thymic output would affect peripheral blood naive T-cell numbers only very slowly, an important aspect of X4 
variants may be their capacity to infect and kill peripheral blood naive CD4 $\mathrm{T}$ cells. In addition, continuously increased levels of immune activation to a higher level in patients with X4 variants may lead to accelerated erosion of the naive $\mathrm{T}$-cell pool. Because naive $\mathrm{T}$ cells are difficult to replace, loss of naive $\mathrm{T}$ cells will interfere with generation of progeny leading to more rapid naive and memory $\mathrm{T}$-cell depletion $[3,4,28]$.

\section{Acknowledgements}

This study was part of the Amsterdam Cohort Studies on AIDS and HIV-1 infection, a collaboration between the Municipal Health Service, the Academic Medical Center, and Sanquin Research at CLB, Amsterdam, The Netherlands. We thank patients and physicians for participating these studies.

Sponsorship: Supported by the Dutch AIDS Foundation (grant 4024).

\section{References}

1. Tersmette M, Lange JMA, De Goede REY, De Wolf F, Eeftink Schattenkerk JKM, Schellekens PthA, et al. Association between biological properties of human immunodeficiency virus variants and risk for AIDS and AIDS mortality. Lancet 1989, 6:983-985.

2. Koot M, Keet IPM, Vos AHV, De Goede REY, Roos MThL, Coutinho RA, et al. Prognostic value of human immunodeficiency virus type 1 biological phenotype for rate of $\mathrm{CD4}^{+}$ cell depletion and progression to AIDS. Ann Intern Med 1993, 118:681-688.

3. Blaak H, Van 't Wout AB, Brouwer M, Hooibrink B, Hovenkamp $\mathrm{E}$, Schuitemaker $\mathrm{H}$. In vivo HIV-1 infection of $\mathrm{CD}^{2} 5 \mathrm{RA}^{+} \mathrm{CD4}^{+}$ cells is established primarily by syncytium-inducing variants and correlates with the rate of $\mathrm{CD}^{+}{ }^{-} \mathrm{T}$ cell decline. Proc Natl Acad Sci USA 2000, 97:1269-1274.

4. Kwa D, Vingerhoed J, Boeser-Nunnink B, Broersen S, Schuitemaker $\mathrm{H}$. Cytopathic effects of non-syncytium inducing and syncytium-inducing human immunodeficiency virus type 1 variants on different $\mathrm{CD}^{+}$T-cell subsets are determined only by co-receptor expression. J Virol 2001, 75:10455-10459.

5. Kaneshima H, SU L, Bonyhadi ML, Connor RI, Ho DD, McCune JM. Rapid-high, syncytium-inducing isolates of human immunodeficiency virus type 1 induce cytopathicity in the human thymus of SCID-hu mouse. J Virol 1994, 68:8188-8192.

6. Uittenboogaart $\mathrm{CH}$, Anisam DJ, Jamieson BD, Kitchen S, Schmid I, Zack JA, et al. Differential tropism of HIV-1 isolates for distinct thymocyte subsets in vitro. AIDS 1996, 10:F9-F16.

7. Pedroza-Martins L, Gurney KB, Torbett BE, Uittenboogaart $\mathrm{CH}$. Differential tropism and replication kinetics of human immunodeficiency virus type 1 isolates in thymocytes: coreceptor expression allows viral entry, but productive infection of distinct subsets is determined at the postentry level. J Virol 1998, 72:9441-9452.

8. Koot M, Vos AHV, Keet RPM, De Goede REY, Dercksen W, Terpstra FG, et al. HIV-1 biological phenotype in long term infected individuals, evaluated with an MT-2 cocultivation assay. AIDS 1992, 6:49-54.
9. Bom- van Noorloos AA, Van Beek AAM, Melief CJM. Cryopreservation of cells for immunological typing of non-Hodgkin's Iymphomas. Cancer Res 1980, 40:2890-2894.

10. Baars PA, Maurice MM, Rep M, Hooibrink B, Van Lier RAW. Heterogeneity of the circulating human $\mathrm{CD4}^{+}$T-cell population: Further evidence that the $\mathrm{CD}^{+}{ }^{+} \mathrm{CD}^{45} \mathrm{RA}^{-\mathrm{CD} 27}-$ T-cell subset contains specialized primed cells. J.Immunol 1995, 154:17-25.

11. Hamann D, Baars PA, Rep MHG, Hooibrink B, Kerkhof-Garde $S R$, Klein MR, et al. Phenotypic and functional separation of memory and effector human CD8 ${ }^{+}$T cells. J Exp Med 1997, 186:1407-1418.

12. Gerdes J, Lemke H, Baisch $\mathrm{H}$, Wacker $\mathrm{H}-\mathrm{H}$, Schwab U, Stein H. Cell cycle analysis of a cell proliferation-associated human nuclear antigen defined by the monoclonal antibody Ki-67. Immunol 1984, 133:1710-1715.

13. Sachsenberg N, Perelson AS, Yerly S, Schokmel GA, Leduc D, Hirschel B, et al. Turnover of $\mathrm{CD4}^{+}$and $\mathrm{CD8}^{+} \mathbf{T}$ Lymphocytes in HIV-1 infection as measured by Ki-67 antigen. J Exp Med 1998, 187:1295-1303.

14. Hazenberg MD, Cohen Stuart JWT, Otto SA, Borleffs JCC, Boucher CA, De Boer RJ, et al. T cell division in human immunodeficiency virus (HIV-1)-infection is mainly due to immune activation: a longitudinal analysis in patients before and during highly active anti-retroviral therapy. Blood 2000, 95:249-255.

15. Mohri H, Perelson AS, Tung K, Ribeiro RM, Ramratnam B Markowitz $M$, et al. Increased turnover of T lymphocytes in HIV 1 infection and its reduction by anti-retroviral therapy. J Exp Med 2001, 194:1277-1287.

16. Kovacs JA, Lempicki RA, Sidorov IA, Adelsberger JW, Herpin B, Metcalf JA, et al. Identification of dynamically distinct subpopulations of $\mathrm{T}$ lymphocytes that are differentially affected by HIV. J Exp Med 2001, 194:1731-1741.

17. Su L, Kaneshima H, Bonyhadi M, Salimi S, Kraft D, Rabin L, et al. HIV induced thymocyte depletion is associated with indirect cytopathogenicity and infection of progenitor cells in vivo. Immunity 1995, 2:25-36.

18. Berkowitz RD, Beckerman KP, Schall TJ, McCune JM. CXCR4 and CCR5 expression delineates targets for HIV-1 disruption of $\mathrm{T}$ cell differentiation. J Immunol 1998, 161:3702-3710.

19. Berkowitz RD, Alexander S, Bare C, Linquist-Stepps V, Bogan M, Moreno ME, et al. CCR5- and CXCR4-utilizing strains of human immunodeficiency virus type 1 exhibit differential tropism and pathogenesis in vivo. J Virol 1998, 72:10108-10117.

20. Eckstein DA, Penn ML, Korin YD, Scripture-Adams DD, Zack JA, Kreisberg JF, et al. HIV-1 actively replicates in naive CD4(+) T cells residing within human lymphoid tissues. Immunity 2001, 15:671-682.

21. Hintzen RQ, De Jong R, Lens SMA, Brouwer M, Baars P, Van Lier RAW. Regulation of CD27 expression on subsets of mature Tlymphocytes. J Immunol 1993, 151:2426-2435.

22. Clark DR, De Boer RJ, Wolthers KC, Miedema F. T cell dynamics in HIV-1 infection. Adv Immunol 1999, 73:301-327.

23. Van de Griend RJ, Carreno M, Van Doorn CJM, Leupers CJM Van den Ende $\mathrm{A}$, Wijermans $\mathrm{P}$, et al. Changes in human $\mathbf{T}$ lymphocytes after thymectomy and during senescence. J Clin Immunol 1982, 2:289-295.

24. Ramos SBV, Garcia AB, Viana SR, Voltarelli JC, Falcão RP. Phenotypic and functional evaluation of natural killer cells in thymectomized children. Clin Immunol Immunopathol 1996, 81:277-281.

25. Livak F, Schatz DG. T-cell receptor alpha locus $V(D)$ J recombination by-products are abundant in thymocytes and mature $\mathrm{T}$ cells. Mol Cell Biol 1996, 16:609-618.

26. Hazenberg MD, Hamann D, Schuitemaker H, Miedema F. T cell depletion in HIV-1 infection: how $\mathrm{CD4}^{+} \mathrm{T}$ cells go out of stock. Nature Immunol 2000, 1:285-289.

27. Grossman Z, Meier-Schellersheim M, Sousa AE, Victorino RMM Paul WE. CD4 T-cell depletion in HIV infection: are we closer to understanding the cause? Nature Med 2002, 8:319-323.

28. Kostense S, Krop E, Blaak H, Schuitemaker H, Miedema F. Normalisation of the $\mathrm{CD}^{+} \mathrm{T}$ cell receptor repertoire after evolution of syncytium inducing HIV-1 variants. AIDS 2000, 14:330-331. 